\title{
Quick Testing for Sexually Transmitted Infections and Factors Related to the Promotion of Elderly Health
}

\begin{abstract}
Karízia Vilanova Andrade1, Adman Câmara Soares Lima1, Evanilde Vilanova Andrade², Eveliny Silva Martins ${ }^{1}$, Janaiana Lemos Uchoa ${ }^{3}$, Camila Almeida Neves de Oliveira', Vanessa da Frota Santos ${ }^{1}$, Monica Oliveira Batista Oriá ${ }^{1}$, Priscila de Souza Aquino ${ }^{1}$
\end{abstract}

\section{Abstract}

Objective: To analyze the search for the elderly to perform a quick testing. Method: A descriptive, quantitative, documentary study conducted with seniors who entered the Center for Quick Testing and Counseling, from June to August 2014, and analyzed in the form of percentages.

Results: The demand for quick testing by the elderly is still incipient, since that, from the 1.314 members attending the service in the period analyzed, only 28 (2\%) were more than 60 years old. Regarding the use of condoms in sexual relations, 21 (75\%) aged not done with any partners. Among men there were identified 1 (4\%) case of syphilis and 1 (4\%) case of hepatitis B; among women, 1 (4\%) case of hepatitis $C$. Conclusion: the expansion of sexually transmitted infections (STIS) in the elderly may be linked to a gap in prevention efforts related to this age group, being it a challenge to the current policies of public health.

\section{Introduction}

Health promotion is understood as the capacity of the community in order to improve their living and health conditions; so, that its field of action proceeds according to the actions of the State in its respective public health policies; of community and individual actions to expand their capabilities and intersectoral interventions. Thus, it is able to develop a comprehensive care and promote significant changes in understanding and improving people's living conditions, in particular the elderly. [1]
1 Federal University of Ceará (UFC), Fortaleza, CE, Brazil.

2 State University of Ceará (UECE), Fortaleza, CE, Brazil.

3 Technologies Center and Health Education (NUTEDS), Fortaleza, CE, Brazil.

\section{Contact information:}

\section{Karízia Vilanova Andrade.}

Address: Departamento de Enfermagem da Universidade Federal do Ceará. Rua Alexandre Baraúna, 1115. Rodolfo Teófilo, CEP: 60430-160. Fortaleza, CE, Brasil.

” kariziaenfermeira@gmail.com

\section{Keywords}

Serologic Tests; Elderly; Health Promotion. 
Aging causes changes in the body as a whole, requiring from the individual adaptations. In this context, the structures responsible for sexual response are also affected, generating the need for adjustments. Discourse about sexuality and aging is complex, since they are still themes full of prejudices by the targeted subjects, and the feelings and the relationships are seen as privileges only for younger people, opposing the view that it is possible for the elderly to remain sexually active and satisfied with their sexual life. [2]

Concerning the absence of comprehensive care to the elderly as a subject with active sexual life, society does not pose promotion possibilities of preventive and promotional health, necessary to reach this age group of the population. Given this, the vision of the elderly, as being unable to produce desires in others, increases their vulnerability to exposure to STIs and AIDS. It is important to point out also that after the development of drugs that enhance sexual performance, the use of prosthesis for erectile dysfunction in men and hormone replacement for women, the elderly have become increasingly sexually active. This advancement promotes quality of life and sexual activity in old age; however, STIs prevention for the elderly needs to keep pace with this evolution. [3]

For these and other reasons, these individuals are exposed increasingly to vulnerable situations; this because rarely their sexual life is questioned in the consultations, predominantly the myth that have decreased sexual rhythm or no longer have sex, hindering early diagnosis of STIS and HIV. Thus, health professionals are of paramount importance in the adoption of educational measures to promote the sexual health of the elderly, and their activeness for the transformation of this reality, to collaborate in addressing the care in aspects of the aging process, so as through the dissemination of information on safe sex and education of this population about the risks of acquiring HIV/ AIDS. [4]
In this perspective, it can be noted that the$r e$ is a fine line between theory and practice for the elderly health promotion in the services performed by a healthcare professional. It is noticed that the actions developed turn to a biologicist care, dressing and fragmented before the action with emphasis on the real need of assisted population, leaving health promotion in the background. Scholars we list there is a tendency, in short time, the number of elderly people infected with HIV will be increased significantly, due to the physical and psychological vulnerability, low access to health services and invisibility with which it is treated the exposure risk elderly to HIVIAIDS, either through sex or illicit drug use. [5]

In the United States, in 1982 only $7.5 \%$ of AIDS diagnoses were in people over 50 years old; in 2006, this population represented $15.5 \%$ of new HIV diagnoses, $20.5 \%$ of AIDS diagnostics and 39\% of all deaths caused by HIVIAIDS. In Australia, it was revealed that a total of 30.486 diagnosed cases of HIV infection to 2011 were 10\% of people over 50 years old. This increase in the number of older people with HIV is associated with the emergence of antiretroviral therapy, which allows people with HIV live longer, reaching old age, in addition to the increase in new cases associated with frequent engagement in risky situations. [6]

In Brazil, 757,042 cases of HIV/AIDS were reported from 1980 to June 2014. Of that amount, 23,271 cases were individuals aged 60 or older. Regarding the involvement of AIDS by sex in old age, 14,756 cases were male and 8,515 female. [7]

There is the challenge of diagnosing HIV/AIDS early in the elderly, because it is a differential diagnosis to a group already exposed to various diseases that can be confused with manifestations of typical diseases in this age group (fatigue and weight loss) resulting in underreported or delayed diagnosis, increasing the likelihood of opportunistic infections and complications. Allied to this there is the complexity of diagnosing the infection in the elderly due 
to the insufficient number of serological testing for this population. [8]

Therefore, the elderly will seek for the service to perform diagnostic tests for STIs, including the real role of health services by not only the unit for individual and specific calls when they are needed. Within this context, the aim of this study was to analyze the search of the elderly to perform a quick testing, from the perspective of comprehensive health care.

\section{Methodology}

The research comprised a descriptive, documentary study, in which it was sought to characterize the elderly who looked for the Center for Quick Testing and Counseling (CTA) on STI/AIDS, from June to August 2014. It is worth noting that the CTA works in Center of Health Carlos Ribeiro Family, located in Fortaleza, Ceará, under the management of Fortaleza City Hall, covering the Regional Executive Secretary I (SER I) covering 15 districts covering about 360.000 inhabitants. [9]

The CTA operates from 08 to 17 hours with a multidisciplinary team, consisting of three nurses, three social workers, two psychologists, a pharmacist, a doctor and three nurses. Health professionals develop prevention activities and treatment of STI/ AIDS/Hepatitis in their service to the population of the city of Fortaleza.

Among the activities performed in the service have been guidance talks about STI, conducting rapid testing for hepatitis $B$ and $C$, syphilis and HIV, by spontaneous demand to all users of the Unified Health System (SUS), treatment and assistance to patients diagnosed with HIV, talk wheels with those living with HIV, medical appointments, nursing visits, social and psychological care.

In the period previous mentioned there were treated in 1314 users to perform tests for HIV, Syphilis, Hepatitis B and C, of these only 28 were 60 or older. Note that this study followed the Resolution $N^{\circ} 466 / 12$ of the National Health Council, which addresses research involving human subjects, to incorporate the four fundamental reference of bioethics: autonomy, non-maleficence, beneficence and justice. [10] The study was approved by the Ethics Committee in the opinion of $\mathrm{N}^{\circ} 660.902$ date of May 29th 2014.

Data collection was conducted through desk research, from consulting the Counseling and Testing Center System (SCTA), established in 2005, in which are recorded all calls made. We evaluated the records of 28 subjects of the study in order to recognize their HIV status for diseases Hepatitis B and C, syphilis and HIV, as well as factors related to health promotion.

Professional care is guided by the form with epidemiological profile, assessment of sexual habits and use of drugs and alcohol. The explanatory variables employed in this study were: month search service, reasons that led to seek the services of the CTA, sex, age, education, marital status, sexual characteristics, type of exposure to HIV and condom use. Possession of the collected data, the data were tabulated, presented in tables and graphs and analyzed by percentage.

\section{Results}

Health promotion is not characterized as a simple task, since it involves different factors throughout this arduous process, as awareness of the manager about its relevance to qualification of health indicators, professional layout in order to improve the assistance provided as well as the awareness of users to form a bond of trust with the team and implement the outlined strategies.

During the months of June to August 2014 were conducted 1314 tests by spontaneous demand for HIV, Syphilis, Hepatitis B and C regardless of age (Figure 1).

Among the tests performed during the period indicated 44 tests were positive for HIV after confirmatory test conducted at the time, which corres- 
Figure 1: Total of examinations for HIV, Syphilis, hepatitis $B$ and hepatitis $C$ in the period from June to August 2014 - Fortaleza/CE. $\varpi$ MAS $=$ FEM

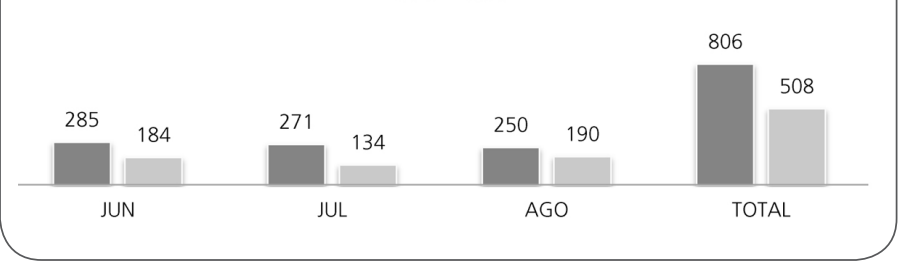

Figure 2: Total number of elderly who attended the CTA to perform rapid testing for HIV, Syphilis, hepatitis B and hepatitis $C$ in the period from June to August 2014. Fortaleza/CE.

$=$ MASC $=$ FEM $=$ TOTAL

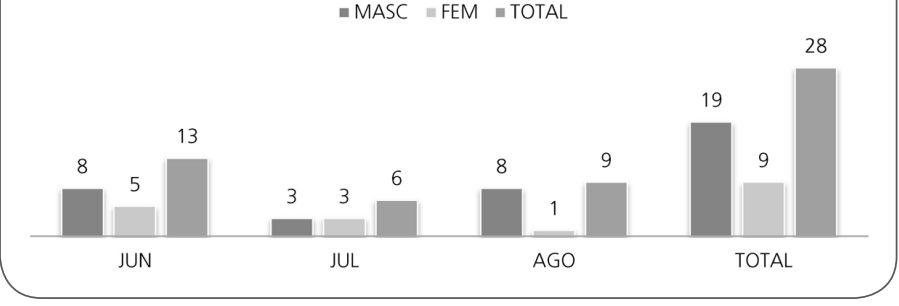

ponds to $3.4 \%$ of total tests. Continuing, in addition to testing for HIV are available in the quick service test for Syphilis and Hepatitis B and C. Through documentary analysis was seized that 5 were positive for hepatitis B $(0.4 \%), 4$ for Hepatitis C $(0.3 \%)$ and 45 (3.5\%) positive VDRL.

Regarding the elderly, it was observed that the demand for quick testing is still in its infancy, considering that the 1,314 members attending the service in the period analyzed only 28 (2\%) were over 60 years old, most of male $(68 \%)(n=19)$. (Figure 2$)$

Throughout the study period there was not detected case of HIV reagent in the elderly; however, it was found 1 case of syphilis in males, 1 case of hepatitis B in men and 1 case of hepatitis $C$ in women. In the current context it is important to note that the elderly are susceptible to infection with STIs, just as any young person who has a sexually active life. Thus, AIDS and other diseases of sexual spread, has appeared in this age group more often than previous decades
Table 1. Main reasons that led to the elderly to the CTA from February to April 2014, Fortaleza/CE.

\begin{tabular}{|l|c|c|}
\hline $\begin{array}{l}\text { Main reason demand for elderly to a } \\
\text { quick testing service }\end{array}$ & N & $\%$ \\
\hline Exposure to risky situation & 14 & 50 \\
\hline Knowledge of serological status & 8 & 28 \\
\hline Prevention & 1 & 4 \\
\hline Symptoms related to AIDS & 1 & 4 \\
\hline Suspicion of STD & 2 & 7 \\
\hline Forwarded by health service & 2 & 7 \\
\hline Total & 28 & 100 \\
\hline
\end{tabular}

Table 2. Report of drug use or drugs for the elderly over the last 12 months, data from February to April 2014, Fortaleza/CE.

\begin{tabular}{|l|c|c|}
\hline Use of narcotics in the last $\mathbf{1 2}$ months & $\mathbf{N}$ & $\%$ \\
\hline Alcohol & 6 & 21 \\
\hline Marijuana & 1 & 4 \\
\hline Cocaine & - & - \\
\hline Crack & 1 & 4 \\
\hline Heroine & - & - \\
\hline Amphetamines & - & - \\
\hline Cigarrets & 5 & 18 \\
\hline No use & 17 & 61 \\
\hline
\end{tabular}

Among the reasons that the elderly seek for the service, the most evident were the risk of exposure (50\%) and knowledge of HIV status (28\%) (Table 1). Health professionals such as general practitioners and geriatricians also requested the tests and submitted to the CTA (7\%), but this data demonstrates the little concern of professionals with STIs in the elderly.

The data related to education revealed the presence of a portion of elderly people with a few years of study, given that $61 \%$ did not complete their studies. It is important to take into account the different user levels of knowledge about transmission, prevention and living with HIV/AIDS, since such differences may be associated with the level of education, which may favor or interfere with the search for realization of testing fast. 
Regarding the use of drugs, $21 \%$ of seniors reported using alcohol in the past 12 months (Table 2). In this sense, it is known that the negative interference for safer sex practices and condom use.

The sexual orientation of the subjects, it was found that most had heterosexual relations (96\%); however, it was reported also bisexual relations (4\%). The Ministry of Health states that in Brazil, heterosexual transmission is the most important feature of the AIDS epidemic dynamics, so this attribute has contributed decisively to the increase of women in cases. [11]

Regarding the use of condoms, 21 (75\%) elderly did not use it with any partners, $3(11 \%)$ used less than half the time, 2 (7\%) used more than half the time and 2 (7\%) when used. 20 (72\%) older reported not using it for not like contraception; 4 (14\%) mentioned that their partners did not accept use and only 1 (3\%) reported having allergic to condoms.

\section{Discussion}

It was obtained in the study in elderly minimum demand for realization of fast testing for STI. It is important to note that in addition to raise awareness about safe behaviors prevention, campaigns to be developed by the Ministry of Health, in partnership with the states and municipalities should draw the attention of society at large to the importance of carrying out the serological tests journals that allow early diagnosis or absence of disease. These tests must be carried out after risky situations, such as the shared use of syringes by drug users or sex without the use of condoms. According to the National Program of STI/AIDS, the Ministry of Health, the number of people living with HIV should increase, since the number of people with sexually active who took the test at least once increased from $40 \%$ in 2009 to $60 \%$ in 2010. [12]

In this sense, literature [12] confirms that the search for new cases of AIDS in Brazil is still a challenge. An estimated 530.000 people are living with HIV/AIDS in the country; whereas these, 135,000 do not know or have never been tested. It is important to note that the rapid test is the main strategy for access to diagnosis. As studies from 2005 to 2011, the number of HIV tests distributed and paid by the Unified Health System (SUS) has doubled: from 3.3 million to 6.3 million units, given that these tests are offered produced by national public laboratories.

Cases of syphilis present in the study depict a major public health problem still existing in Brazil, and, once installed, can affect many organs and systems, as well as cause a variety of symptoms, mimicking numerous diseases. In the elderly, we must be aware of the differential diagnosis of systemic diseases in this population, often ignored by the professionals, the gap acceptance of the elderly as sexually active. [13]

In addition, they identified cases of hepatitis in the elderly. The last population-based prevalence study of infections with hepatitis A, B and C [14], conducted between 2005 and 2009 in all 26 state capitals and the Federal District, showed that in relation to hepatitis $B$ the overall result of the prevalence of positivity serological indicative of exposure to infection (anti-HBc), aged between 10 and 69 years old; it was 7.4\%, ranking all the capitals of Brazil as low endemicity. Moreover, the risks of contamination should not be subtracted from the population, as well as prevention practices should be effective.

To not pay attention to the elderly as a subject with active sex life, society does not raise possibilities also building and promoting preventive measures needed to reach this age group of the population. Given this, the literature [15] confirms that the vision of the elderly as an asexual being unable to produce or desires in others, plus the advent of the use of various medications, increases their vulnerability to exposure to STIS and AIDS. However, demand for serologic detection means these infections it is essential for this population, as well as educational 
work about preventive means of contracting these diseases as the use of male and female condoms.

The human being needs to be seen as a complex being, in view of its various dimensions: biological, psychological, social, spiritual, etc. Some scholars consider that the major changes for the elderly are restricted to physical changes in its physical dimension, but it is necessary to realize that with the passage of time also changes are processed in the form of thinking, feeling and acting of human beings who pass by this stage of the process of living. It is essential, especially in a country like Brazil, where the increase of the elderly population is on the rise, a reflection on the whole way the aging process, so that every day we are able to meet the needs of old age. [16]

In the current context, it is important to note that the elderly are susceptible to sexually transmitted infections in the same way that any young person who has a sexually active life. Given the above, AIDS and other diseases of sexual spread, has appeared in this age group more often than decades ago. [17]

According to the data obtained in the study, only two subjects were referred by health service to the CTA (7\%), which reveals the belief that advancing age and the decline of sexual activity are inextricably linked and can be one of the factors of forms of neglect that professionals deal with the quality of life in this population. Studies report that health professionals do not value sexual complaints of elderly patients. So if health professionals consider naturally the occurrence of sexual activity in the elderly, it would be routine to request and referral of that person to the examination of HIV. [18, 19]

It is believed that an important part of the implementation of the health policy process are the health professionals involved and which constitute essential in the role of health promoters. Thus, it is necessary that the health professional staff present solving the health problems of this population and as a key part of health promotion, these professionals should be in constant training and learning process; so that they can provide for the elderly comprehensive care, individual and collective.

Most elderly had low education. The literature outlines 20 users with more advanced level of education have more favorable preventive measures, as they tend to better assimilate the information; have easier access to health services and look for condoms. In addition, access to education is linked to decreased risk behaviors. However health professionals have obvious gap when working sexuality in the elderly. [21]

Elderly people who sought the CTA to perform tests showed alcohol consumption in the last year. The alcohol consumption is one of the main risk factors for unprotected sex, a study released by the journal The Lancet. A survey by the Department of STD, AIDS and Viral Hepatitis Ministry of Health also no confirmation of this association. In research conducted in Brazil with people between 15 and 64 it was found that $72.7 \%$ of subjects in the study believe that the use of alcohol or drugs can cause people to have sex without condoms. About $24 \%$ of respondents have already ceased to use condoms under the influence of alcohol or drugs. Experts say that, in some cases, excess alcohol causes the person to forget the condom. In others, the person know he needs to use, and does not have a condom on time, have sex anyway. [22]

More than half of the elderly confirmed not use condoms during sexual intercourse. On the nonuse of condoms among the elderly, the factors that contribute to this behavior are the erection of the penis changes in men and women the changes that occur in the reproductive system because of age and not to fear unwanted pregnancy. Another point to consider: the elderly who have a stable partner for which there is perception of lower vulnerability and understand that they were not exposed, since commonly maintain a single partner, this condition appears to be a person's choice 
elderly for not using condoms because they have a relationship of trust and share the idea that it is unnecessary to adopt any method of prevention of STI/HIV/AIDS. [23]

In this perspective, health care for elderly involves the provision of services that allow access, reception and respect the limitations pertaining to this population. Therefore, health professionals need to be trained with respect to knowledge, skills and attitudes in order to organize and implement protocols to program actions related to the needs of the elderly in an integrated way with the other practices of the network of social care. Therefore, the estimated supply and the use of primary care services allow us to evaluate the effectiveness of policy aimed at this population group.

\section{Conclusion}

Given the research proposal, it can be understood that the elderly population is at risk, since intercourse is unprotected and mostly no condom use in their possible sex. It was observed that the demand of the elderly for a quick testing is still in its infancy, compared to the need of knowledge of the serologic profile of this population. Additionally, there is the use of alcohol and other illicit drugs, which has negatively compromise the safe sex practices and condom use.

It is considered as the study of limiting the number of elderly people attending the service during the study period (03 months), which invites the other scholars in future studies to recognize the elderly, their vulnerabilities and reasons for non-attendance to services of health.

By professional experience in care for the elderly and the results of this study it infers that this population has an active sex life, a fundamental aspect to be considered in local actions in national services and with the leadership of the Ministry of Health. Current studies portray expansion of AIDS in the elderly, which can be linked to a gap in preven- tion efforts with this group, and a challenge to the current public health policies, since campaigns are binding only to the young population.

So, it constitutes an incitement to all health professionals a direct approach to this population, from educational strategies carried out by qualified people and can promote a change in behavior of the elderly, especially on ways to prevent STIs, including HIV. As well as offering rapid testing to this population through a mobilization that encompasses sexuality and ways of prevention strongly include the elderly.

Therefore, promoting effective health as an essential care strategy, and through this tool changes in lifestyle for the elderly should be proposed, as well as family members and caregivers, with design improvements in health and living conditions to this population. For the goal is achieved, that is, improving the quality of life of the elderly, it is important that they can acquire sufficient knowledge to achieve autonomy, independence and self-care ability to remain active in their daily life activities and interpersonal relationships. Thus, it is essential the importance of health professionals who work daily in the primary health care services, particularly nursing in line with managers.

In this light, it is believed that health services should lead to problematic spaces of everyday concerns and promoting the health of the elderly, which go far beyond aging with its natural and physiological characteristics, to allow these individuals to be heard and hear the others.

\section{References}

1. Janini JP, Bessler D, Vargas AB. Educação em saúde e promoção da saúde: impacto na qualidade de vida do idoso. Saúde Debate. 2015; 39 (105): 480-490.

2. Paulino MCF, Bernardes CA, Souza LPS, Fonseca ADG, Pinheiro MAM, Silva CSO et al. Análise dos comportamentos sexuais de idosos cadastrados em uma Estratégia Saúde da Família. Revista Kairós Gerontologia. 2014; 17(4):49-61. 
3. Garcia GS, Lima LF, Silva JB, Andrade LDF, Abrão FMS. Vulnerabilidade dos Idosos frente ao HIV/Aids: Tendências da Produção Científica Atual no Brasil. DST - J bras Doenças Sex Transm. 2012;24(3):183-188.

4. Mascio MBM, Balbino AP, D'Souza PFR, Kalinke LP. Sexualidade na terceira idade: medidas de prevenção para doenças sexualmente transmissíveis e AIDS. Rev Gaúcha Enferm. 2011; 32 (3): 583-9.

5. Cambruzzi C, Lara GM. HIVIAIDS em idosos brasileiros. Revista Conhecimento Online. 2012; 1(4): 1-12.

6. Minichiello V, Rahman S, Hawkes G, Pitts M. STI epidemiology in the global older population: emerging challenges. Perspect Public Health. 2012; 132(4):178-181.

7. BRASIL. Ministério da Saúde. Serviço de Vigilância em Saúde. Secretaria de Vigilância em Saúde - Departamento de DST, Aids e Hepatites Virais. Boletim Epidemiológico HIV - AIDS. Brasília: Ministério da Saúde, ano III, n. 1, 2014.

8. Serra A, Sardinha HL, Pereira ANS, Lima SCVS. Percepção de vida dos idosos portadores do HIVIAIDS atendidos em centro de referência estadual. Revista Saúde em Debate. 2013; 37(97): 294-304

9. Prefeitura Municipal de Fortaleza [Internet]. Cidade: dados geográficos. Fortaleza - CE, 2014. Disponível em: <http://www. fortaleza.ce.gov.br/>. Acesso em: 30 ago. 2014

10. Brasil, Ministério da Saúde. Resolução 466/12. Conselho Nacional de Ética em Pesquisa. Diretrizes e Normas Reguladoras de Pesquisa Envolvendo Seres Humanos. Brasília - DF, 2012.

11. Souza NR, Bernardes EH, Carmo TM, Nascimento E, Silva E, Souza B, Bento PF. Perfil da População Idosa que Procura o Centro de Referência em DST/Aids de Passos/MG. DST - J Bras Doenças Sex Transm. 2011; 23(4):198-204.

12. Brasil, Ministério da Saúde. AIDS no Brasil. Departamento de DST, AIDS e Hepatites Virais/SVS/MS. Brasília - DF, 2012.

13. Mello JLC, Maciel AC, Linhares FAC, Pinto IF. Sífilis: uma grande simuladora. Revista Brasileira de Medicina. 2014; 71 (9): 303305.

14. Brasil, Ministério da Saúde. Boletim Epidemiológico Hepatites Virais. Secretaria de Vigilância em Saúde - Departamento de DST, Aids e Hepatites Virais. Ano III - n 1. Brasília - DF, 2012.

15. Nascimento RG, Monteiro EL, Ferreira LS, Santos ZNL. Nível de conhecimento de idosos comunitários em relação ao HIV/Aids: estudo exploratório na rede básica de saúde de Belém, Pará, Brasil. RBCEH. 2013; 10(1): 113-122.

16. Fechine BRA, Trompieri N. O processo de envelhecimento: as principais alterações que acontecem com o idoso com o passar dos anos. InterSciencePlace. 2012; 20 (1): 106-194.

17. Santos AFM, Assis M. Vulnerabilidade das idosas ao HIVIAIDS: despertar das políticas públicas e profissionais de saúde no contexto da atenção integral: revisão de literatura. Rev. Bras. Geriatr. Gerontol. 2011; 14(1): 147-57.
18. Gurgel SN, Lubenow JAM, Moreira MASP, Ferreira OGL, Pinho TAM, Nogueira JÁ. Vulnerabilidade do idoso ao HIV: revisão integrativa. Rev enferm UFPE on line. 2014; 8 supl. 1:2487-93.

19. Peixer TC, Ceolin T, Grosselli F, Vargas NRC, Casarin ST. Sexualidade na terceira idade: percepção de homens idosos de uma estratégia de saúde da família. J Nurs Health. 2015;5(2):13140.

20. Okuno MFP, Fram DS, Batista REA, Barbosa DA, Belasco AGS. Conhecimento e atitudes sobre sexualidade em idosos portadores de HIVIAIDS. Acta Paul Enferm. 2012;25(Número Especial 1):115-21.

21. Bezerra VP, Serra MAP, Cabral IPP, Moreira MASP, Almeida SPF, Patricio ACFA. Práticas preventivas de idosos e a vulnerabilidade ao HIV. Rev Gaúcha Enferm. 2015;36(4):70-6.

22. Brasil, Ministério da Saúde. Álcool dificulta a prevenção da Aids. Departamento de DST, AIDS e Hepatites Virais. Brasília - DF, 2014.

23. Silva LVS, Minervino SS, Bueno AAB, Fassarella CS. O uso do preservativo e a prevenção de doença sexualmente transmissível na terceira idade. Revista Rede de Cuidados em Saúde. 2014; 8 (1): 1-11.

\section{Publish in International Archives of Medicine}

International Archives of Medicine is an open access journal publishing articles encompassing all aspects of medical science and clinical practice. IAM is considered a megajournal with independent sections on all areas of medicine. IAM is a really international journal with authors and board members from all around the world. The journal is widely indexed and classified Q1 in category Medicine. 